\title{
The start of an academic year like no other!
}

2020 has been, and continues to be, a year like no other: The World Health Organisation (WHO) declared COVID-19 a global pandemic in March (WHO, 2020) and due to the highly contagious nature of the virus, the government put in place stringent measures to slow down its spread: including social distancing (Gov.UK, 2020). Social distancing had a significant impact on all Higher Education Institutions (HEIs) in the United Kingdom (UK), with campuses closing and face to face teaching being suspended and replaced by Emergency Remote Teaching (ERT) (Bozkurt and Sharma, 2020; Hodges et al., 2020).

As a Senior Lecturer in Higher Education (HE), this is historically the busiest time of the academic year. We are usually welcoming our new students onto campus; helping them navigate their new surroundings and introducing them to their programme, lecturers and fellow students, as they embark on the most challenging and rewarding of journeys. But not this year... as social distancing measures remain in place, September 2020 cohort's induction into HE will be like no other, with inductions being largely conducted remotely, rather than face to face.

That said, the current extraordinary situation should not dictate the quality of learning opportunities and experiences: life and education must and should go on with the same enthusiasm, excitement and anticipation as every other year. This is a time to celebrate new beginnings, regardless of the current constraints. On revisiting a 'survival guide' for commencing students from 2015 (Power, 2015): the advice is still relevant; the top tips from students still pertinent, supportive and insightful - I would encourage commencing students to read it.

To the cohort of September 2020: congratulations on securing a place on one of the most competitive degree programmes in the UK. Buckle your seatbelts, as you're in for a rollercoaster ride at times! Let's remember you not as the Covid Cohort, but as the cohort who started their training in the historic first global International Year of the Nurse and Midwife 2020 (NHS England, 2020). What better year to embark on the journey to realising your dreams of being 'with woman'. Good Luck to you all!

\section{References}

Bozkurt A, Sharma R (2020) Emergency remote teaching in a time of global crisis due to CoronaVirus pandemic [editorial]. Asian Journal of Distance Education 15 (1) i-vi

Gov.uk (2020) Coronavirus (COVID-19). Gov.UK [online]. Available from: https://www.gov.uk/coronavirus [Accessed 03.08.2020]

Hodges C, Moore S, Lockee B, Trust T, Bond A (2020) The difference between Emergency Remote Teaching and Online Learning. Available from:

https://er.educause.edu/articles/2020/3/the-difference-between-emergencyremote-teaching-and-online-learning [Accessed 04.09.2020] 
NHS England (2020) International Year of the Nurse and Midwife 2020.

Available from: https://www.england.nhs.uk/year-of-the-nurse-and-midwife2020/. [Accessed 07.09.2020]

Power A (2015) Welcome to class: A survival guide for commencing student midwives. British Journal of Midwifery 23 (10) 746-748

World Health Organisation (WHO) (2020) Coronavirus disease (COVID-19) Pandemic. World Health Organisation [online]. Available from:

https://www.who.int/emergencies/diseases/novel-coronavirus-2019 [Accessed 05.08.2020] 